\title{
Merchandise Import Demand Function in Saudi Arabia
}

\author{
Mohamed Abbas Ibrahim ${ }^{1}$ \\ ${ }^{1}$ Department of Business Administration, College of Business Administration, Majmaah University, PO Box 11952 , \\ Majmaah, Saudi Arabia. \\ Correspondence: Mohamed Abbas Ibrahim, College of Business Administration, Majmaah University, PO Box 11952, \\ Majmaah, Saudi Arabia.
}

Received: December 1, 2014

Accepted: December 18, 2014 Available online: December 26, 2014

doi:10.11114/aef.v2i1.626

URL: http://dx.doi.org/10.11114/aef.v2i1.626

\begin{abstract}
Merchandise imports in Saudi Arabia is growing steadily and very rapidly, at an average growth rate of 10.04 percent/year during 1975-2011. So, this study is very important to know the merchandise imports determinants in Saudi Arabian economy. This study empirically estimates the critical parameters of merchandise import demand determinants for Saudi Arabia by using Ordinary Least Squares (OLS) approach and Error Correction model during the period (1975-2011). The empirical results obtained show that, in both long run and short run, there are positive and significant relationships between the demand for merchandise import and real gross domestic product, gross capital formation expenditure, private consumption expenditure, government consumption expenditure and the relative price of imports to domestic price. On the other hand, there are positive but insignificant relationship between the demand for merchandise import and international reserves either in the long run or the short run.
\end{abstract}

JEL Classification: C22, F62, P33

Keywords: International Trade, Merchandise Import Demand, Error Correction model, Saudi Arabia.

\section{Introduction}

Imports play an important role in developing economies. However, through it countries can safe goods and services that can't be produced domestically. Many empirical studies estimated the import demand functions for advanced countries and developing countries in order to determine economic variables that affect the behavior of merchandise import demand over time.

The paper is structured as follows: Introduction in Section 1. Section 2 provides some stylized facts about Saudi economy and the behavior of merchandise import demand determinants in Saudi Arabia. Section 3 presents the theoretical background on which the models are based and also gives an empirical review of the literature. Section 4 discusses the data, evaluates the specifications of the economic models and describes the econometric methodology that will be adopted. Section 5 reports on the empirical results and Section 6 summarizes the concluding remarks.

\section{Stylized Facts about Saudi Economy and the Behavior of Merchandise Import Demand in Saudi Arabia}

The Saudi economy recorded high growth in 2013 as global economic recovery lifted up oil prices, and increased fiscal spending by the government boosted domestic demand and accelerated the growth in non-oil gross domestic product. On the same line, the actual budget recorded a surplus of 180.35 billion Saudi riyal (SAR) or 6.4 percent of GDP in 2013 but this surplus is less than the surplus of 2012 which amounted by SAR 374.09 billion or 13.6 percent of GDP. On the other hand, the ratio of public debt to GDP declined from 3.6 percent in 2012 to 2.7 percent in 2013 . The current account of the balance of payments recorded a surplus for the sixteenth year consecutively amounting to SAR 497.4 billion or 17.7 percent of GDP in 2013 (Saudi Arabian Monetary Agency (SAMA), 2014).

As shown in table 1, total trade has increased from 44.47 billion dollar to 574.2 billion dollar during the period 1975 2011 , with average growth rate $7.35 \%$. Although a trade/GDP ratio decreased from $95.57 \%$ to $85.77 \%$ at the same period but it still high trade/GDP ratio, so the economy is considered as one of the highest trade openness economies (World Bank, World Bank Development Indicator, http://data.worldbank.org/indicator/) 
.Table 1. Some Key Trade Indicators of Saudi Arabia (1975-2011)

\begin{tabular}{lllll}
\hline & \multicolumn{2}{l}{ Value (billion dollar) } & \multicolumn{2}{l}{$\%$ of GDP* } \\
\cline { 2 - 5 } & 1975 & 2011 & 1975 & 2011 \\
\hline Merchandise Exports & 29.67 & 364.74 & 63.77 & 54.49 \\
Services Exports & 4.63 & 11.48 & 9.95 & 1.71 \\
Total Exports & 34.3 & 376.22 & 73.72 & 56.20 \\
Merchandise Imports & 4.21 & 131.66 & 9.05 & 19.67 \\
Services Imports & 5.96 & 66.32 & 12.81 & 9.9 \\
Total Imports & 10.17 & 197.98 & 21.86 & 29.57 \\
Total Trade & 44.47 & 574.2 & 95.57 & 85.77 \\
\hline
\end{tabular}

Table 2 illustrates that trade account surplus increased from 24.31 billion dollar to 178.24 billion dollar during the period 1975-2011, with annual average growth rate amounted by 5.71 percent. Although the merchandise account balance increased dramatically with average growth rate 6.34 percent during the period 1975-2011, but almost of this increase was because the growth of oil exports. On the other hand services account balance during the same period was suffering from increasing deficit with average growth rate 10.88 percent which swallowing the most of merchandise account balance surplus. The higher average growth rate of the services account balance deficit increases the necessity of find solutions for this problem.

Table 2. Trade Account (1975-2011)

\begin{tabular}{|c|c|c|c|c|c|}
\hline & \multicolumn{2}{|c|}{ Value (billion dollar) } & \multirow{2}{*}{$\begin{array}{c}\begin{array}{c}\text { Average Annual Growth } \\
\text { rate }(\%)\end{array} \\
1975-2011\end{array}$} & \multicolumn{2}{|c|}{$\%$ GDP* } \\
\hline & 1975 & 2011 & & 1975 & 2011 \\
\hline Merchandise Exports & 29.67 & 364.74 & 7.22 & & \\
\hline Merchandise Imports & 4.21 & 131.66 & 10.04 & & \\
\hline Merchandise Account Balance & 25.46 & 233.08 & 6.34 & 54.71 & 34.81 \\
\hline Services Exports & 4.63 & 11.48 & 2.55 & & \\
\hline Services Imports & 5.96 & 66.32 & 6.92 & & \\
\hline Services Account Balance & -1.33 & -54.84 & 10.88 & 2.86 & 8.19 \\
\hline Trade Account Balance & 24.13 & 178.24 & 5.71 & 51.86 & 26.62 \\
\hline
\end{tabular}

In analyzing the Saudi Arabian merchandise import performance, the structure of merchandise import has to be analyzed. Table 3 presents the structure of merchandise import in 1975 and 2011; the average growth rates of merchandise imports components during the period and its shares of total merchandise imports. We can observe that ores and metals achieved the highest yearly average growth rate during the period 1975-2011, which generate the increase of the share of merchandise imports in 2011. Manufacturers and food imports also achieved high average growth rates during the same period although the manufacture's share had declined.

Table 3. The Structure of Merchandise Imports and its Yearly Average Growth Rates 1975-2011

\begin{tabular}{lccccc}
\hline \multirow{2}{*}{ Merchandise Imports } & \multicolumn{2}{c}{ Value (billion dollar) } & $\begin{array}{c}\text { Yearly Average Growth } \\
\text { Rate* }(\%)\end{array}$ & \multicolumn{2}{c}{ \% of Merchandise Imports* } \\
\cline { 2 - 6 } & 1975 & 2011 & $1975-2011$ & 1975 & 2011 \\
\hline Manufactures & 3.42 & 101.08 & 9.86 & 81.32 & 76.77 \\
Agricultural raw materials & 0.06 & 1.11 & 8.44 & 1.46 & 0.84 \\
Food & 0.66 & 19.2 & 9.81 & 15.65 & 15.19 \\
Ores and metals & 0.04 & 7.06 & 15.45 & 0.88 & 5.36 \\
Fuel & 0.03 & 0.37 & 7.23 & 0.69 & 0.28 \\
Other & - & 2.84 & - & - & 1.56 \\
Total & 4.21 & 131.66 & 10.04 & 100 & 100
\end{tabular}

Source: http://data.worldbank.org/indicator/.* calculated by the author. 
Figure 1 illustrate the changes of the structure of merchandise imports during the period 1975-2011. Fuel and agricultural raw materials imports shares witnessed an obviously decline at the same period although the positive average growth rates during the period.

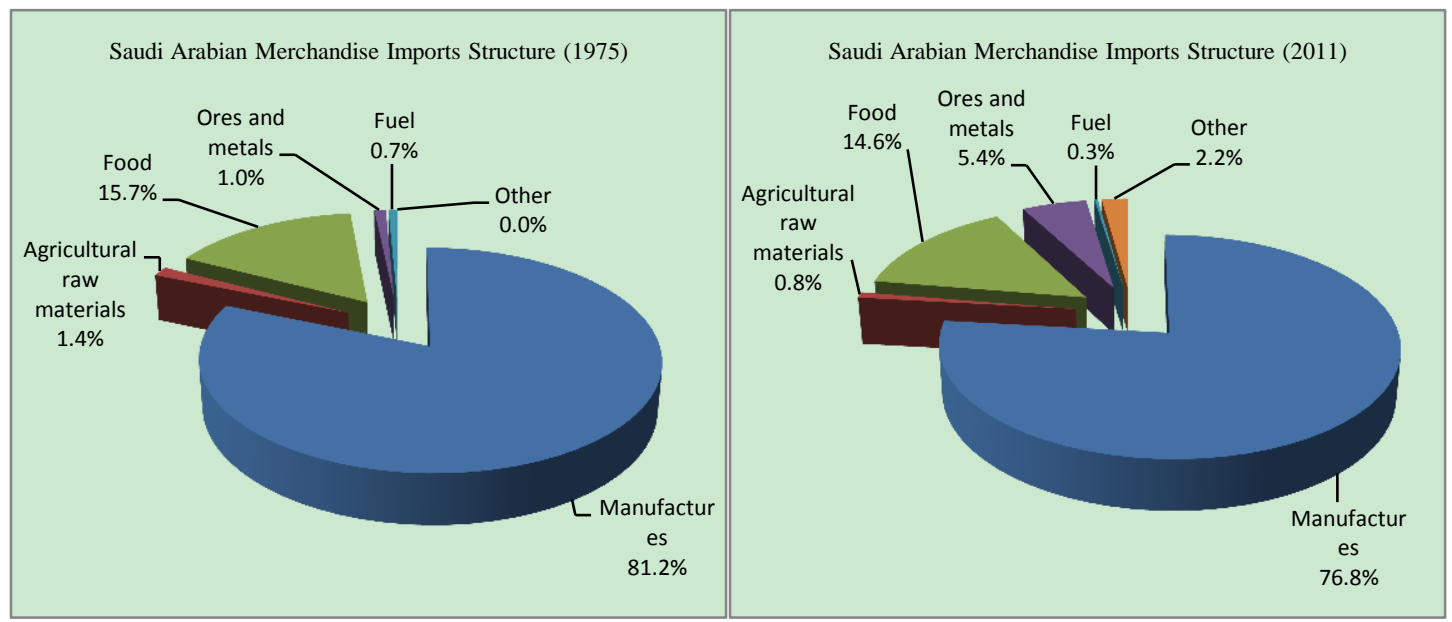

Figure 1. The Structure of Saudi Arabian Merchandise Imports 1975-2011

Source: Drawn by the author from Table 3.

\section{Recent Empirical Studies}

There is no doubt that imports play an important role in developing economies. However, through it countries can safe goods and services that can't be produced domestically. There are applied empirical studies estimating import demand functions either for advanced countries or developing countries in order to determine economic variables that affect the behavior of import demand over time.

To the best of the researcher's knowledge, there are no studies for Saudi Arabia that investigated the merchandise import determinants but few studies estimated the import demand function. However Doroodian et al. (1994) investigated the import demand determinants for Saudi Arabia based on annual data for the period 1963-90. The results suggested a number of aspects that characterize the Saudi Arabia import demand function. First, econometric evidence illustrated that, for standard specifications of the import demand function, the log-linear formulation was more appropriate than the linear one. Secondly, empirical result showed that, in the case of Saudi Arabia, the relative price formulation of the traditional import demand function is inappropriate for estimating elasticities of import demand. Aldakhil and Al-Yousef (2002) estimated Saudi Arabia's aggregate demand for imports during the period 1968-98 by using cointegration analysis and error correction approach. They found that, domestic price, import price, and income are important in determining the import demand. Aljebrin and Ibrahim (2012) estimated the critical parameters of import demand determinants for GCC countries (Bahrain, United Arab Emirates, Kuwait, Oman Qatar and Saudi Arabia) by using annual time series-cross section data (1994-2008) and by applying panel Seemingly Unrelated Regression (SUR) model. The empirical results showed that, in both long run and short run, there are positive and significant relationships between the demand for imports and real income, private consumption, international reserves and gross capital formation. On the other hand, there are negative and significant relationships between the demand for imports and the relative price of imports to domestic price and government consumption in the long run, but negative and insignificant relationships in the short run. Metwally (2004) investigated the impact of the fluctuations in oil exports on Gulf Cooperation Council (GCC) spending on imports and estimated the long-run relationship between the imports of each GCC member and the macroeconomic components of final expenditure (exports, government consumption, investment and private consumption) using the Johansen multivariate cointegration analysis. He confirmed that the demand for imports was highly elastic with respect to GDP in all GCC countries studied (with the exception of Oman) during the last three decades.

On the other hand, many authors investigated the import demand function in developing countries. For Turkey, Erlat and Erlat (1991) analyzed Turkish export and import performance by using annual data for the period 1967-87. Export supply, export demand and import demand functions were investigated by ordinary least squares (OLS) first, and then three equations were estimated as a set of seemingly unrelated regressions (SURs). The total volume of imports was regressed on domestic real income, real international reserves, price of imports divided by domestic prices and one period lagged value of the dependent variable. Two dummies were introduced for the years 1978 and 1979 to explain structural shifts. International reserves were found to be the most important variable in explaining import demand. 
Relative prices, however, had no significant explanatory power on import demand. Kotan and Saygili (1999) investigated an import demand function for Turkey. They incorporated two different model specifications to investigate the import demand function for Turkey. The estimation performance of the two models was compared and contrasted for the period 1987:Q1-1999:Q1 by using quarterly data. The significance of variables that affected import demand was individually and jointly investigated. Also, the short run elasticities of the two models were compared. The first model estimated imports using the Engle-Granger approach. The results confirmed that in the long run, income level, inflation rate, nominal depreciation rate and international reserves insignificantly affect imports. The second approach models import demand using the Bernanke-Sims structural vector autoregressive (VAR) method. The results showed that anticipated changes in the real depreciation rate and unanticipated changes in the income growth and real depreciation rate have significant effects on import demand growth.

Mohammed and Tang (2000), used the Johansen and Juselius cointegration technique and investigated the determinants of aggregate import demand for Malaysia, over the period 1970-1998. The results showed that while all expenditure components had an inelastic effect on import demand in the long run, investment expenditure had the highest correlation with imports followed by final consumption expenditure. Expenditure on exports was found to have the smallest correlation with imports. They also found a negative and inelastic relationship between relative prices and import demand. All results confirmed the statistically significant relationship at the 1 per cent level.

Alias and Tang (2000) investigated the long-run relationship between Malaysian aggregate imports and the components of final demand expenditure and relative prices using the Johansen multivariate cointegration analysis. An error correction model is suggested to model the short-run response of imports to its determinants. Annual data for the period 1970 to 1998 are used. The long-run relationship between aggregate imports and the macroeconomic components of final demand expenditure namely public and private consumption expenditure, investment expenditure and exports, is investigated because the different components of final demand might have different import contents. The results of the analysis showed that the components of final demand expenditure and relative prices are all important in determining aggregate demand for imports in both the long-run and the short-run.

Dutta et al. (2006) tested the behavior of Indian aggregate imports during the period 1971-1995. In their empirical analysis of the aggregate import demand function for India, cointegration and error correction modeling approaches were adopted. In the aggregate import demand function for India, import volume is found to be cointegrated with relative import price and real GDP. The aggregate import volume is found to be price-inelastic. The value of income elasticity of demand for imports lagged two years is greater than unity, implying that the demand for imports increases more than proportionately to the increase in real gross domestic product.

Sinha's (2001) study showed that the price and income demand elasticities are inelastic in Japan, India, the Philippines, Thailand and Sri Lanka. Bahmani-Oskooee et al. (1998), tested demand import function for 30 countries during the period 1970-1992. They found that both price and income elasticities of import demand were high in the most cases.

For, developed countries, Carone (1996) investigated the American demand for imports using quarterly data 1970 to 1992 based on the cointegration and error correction approaches. They confirmed the statistically significant long-run relationship between the import demand function and real income and relative prices. Stirbock (2006) introduced a single error-correction analysis of German, euro-area and non-euro-area import demand for the 1980-2004 period and found that, German import demand is driven largely by domestic and foreign demand and less by changes in relative prices.

\section{The Model and the Methods}

Phillips-Perron (PP) unit root test is employed to test the integration level and the possible co-integration among the variables (Phillips and Perron, 1988). The PP procedures, which compute a residual variance that is robust to auto-correlation, are applied to test for unit roots.

An OLS model is estimated to explain the demand for merchandise imports in Saudi Arabia by using data from 1975 to 2011.

Accordingly, the estimated demand function for merchandise imports in Saudi Arabia involves the following variables;

For long run:

$$
\begin{aligned}
\log (R M I)= & C_{0}+C_{1} \log (R G D P)+C_{2} \log (R F R)+C_{3} \log (R I N V)+C_{4} \log (R P C) \\
& +C_{5} \log (R G C)+C_{6} \log (P M P D)+\xi
\end{aligned}
$$

Where RMI is the real value of merchandise imports to real GDP ratio, RGDP is the real gross domestic product; RFR is the value of international reserves to real GDP ratio; RINV is the real value of gross capital to real GDP ratio; RPC is the real value of private consumption expenditure to real GDP ratio; RGC is the real value of public consumption expenditure to real GDP ratio; The relative price variable PDPM is given by the indicative ratio of import price index 
(proxied by consumer price index of Saudi Arabia to consumer price index of United States.

We sourced data for the study from World Development Indicators (2014) and Saudi Arabian Monetary Agency (SAMA, 2014). All variables were transformed into natural logarithm in order to avoid the problem of heteroscedasticity and obtain elasticities.

If the variables are cointegrated, they can be represented equivalently in terms of a short run OLS framework. The most common procedure to test for cointegration is the Engle-Granger two-step estimation technique (EG). The first step in this method implies fitting the long-run relationship in levels by OLS and using the resulted residuals to test the hypothesis of cointegration by applying the PP test. If the hypothesis of cointegration is accepted, then there exists an error correction representation (Phillips and Perron, 1988). Then, the next step is to construct the error correction model, which represents the short-run dynamics.

$$
\begin{aligned}
& \Delta \log \left(R M I_{t}\right)=C_{0}+C_{1} \Delta \log \left(R G D P_{t}\right)+C_{2} \Delta \log \left(R F R_{t}\right)+C_{3} \Delta \log \left(R I N V_{t}\right)+C_{4} \Delta \log \left(R P C_{t}\right) \\
& +C_{5} \Delta \log \left(R G C_{t}\right)+C_{6} \Delta \log \left(P D P M_{t}\right)+C_{7} E C T_{t-1}
\end{aligned}
$$

Where ECT(-1) is one lag error correction term and $\Delta$ is the difference operator.

Another procedure to test for cointegration is developed by Johansen and Julesius $(1988,1992)$, and it is known as the maximum likelihood (ML) approach. This method estimates and tests for multiple cointegrating vectors (multivariate cointegration). It applies the analysis of the vector auto-regressive (VAR) model where all variables are treated as endogenous.

The sign and significance of the coefficient of error correction term $\mathrm{ECT}_{\mathrm{t}-1}$ describes about the existence of short run relationship. Its value and sign tells about the speed and convergence or divergence to or from the long run equilibrium. Its negative value indicates about the convergence whereas its positive value indicates about the divergence. A significant coefficient of error correction with negative sign is considered as a further proof of the existence of stable long run relationship (Banerjee et al., 1998).

\section{Empirical Results}

Phillips-Perron (PP) unit roots test is calculated for individual series to provide evidence as to whether the variables are stationary and integrated of the same order.

The results for each variable appear in Table 4. The lag parameter in ADF test is selected by Akaike information criterion (AIC) to eliminate the serial correlation in residual (Akaike, 1973). As shown in Table 4, the null hypothesis of a unit root can't be rejected for levels of all variables but the null hypothesis is rejected for the first differences of all variables. Therefore, we conclude that the series are integrated of order one.

Table 4. PP Unit Root Test Results

\begin{tabular}{lcc}
\hline Variable & & PP \\
\hline $\log ($ RMI $)$ & Level & -2.038640 \\
& First Diff. & $-5.638064^{\mathrm{a}}$ \\
$\log (\mathrm{RGDP})$ & Level & -1.858033 \\
& First Diff. & $-6.194450^{\mathrm{a}}$ \\
$\log (\mathrm{RFR})$ & Level & -1.322109 \\
& First Diff. & $-4.963566^{\mathrm{a}}$ \\
$\log (\mathrm{RINV})$ & Level & -2.485536 \\
& First Diff. & $-6.760274^{\mathrm{a}}$ \\
$\log (\mathrm{RPC})$ & Level & -1.710024 \\
& First Diff. & $-5.974543^{\mathrm{a}}$ \\
$\log (\mathrm{RGC})$ & Level & -1.932446 \\
& First Diff. & $-7.851783^{\mathrm{a}}$ \\
$\log (\mathrm{PMPD})$ & Level & -1.253100 \\
& First Diff. & $-2.877478^{\mathrm{c}}$
\end{tabular}

Notes: Phillips and Perron (1988) unit root test with the Ho: Variables are I (1); a, and c indicate significance at the 1\% and $10 \%$ levels respectively.

Cointegration analysis refers to the process of getting equilibrium or long-run relationships among non-stationary 
variables. The idea is that although the variables are non-stationary, a linear combination of them may be stationary, given that all variables are integrated of the same order (Engle and Granger, 1987). The vector that links the variables in the long-run relationship is called the cointegrating vector.

The estimated OLS model as it shown in Table (A-1) is:

$$
\begin{aligned}
& \log \left(R M I_{t}\right)=-2.89+0.27 * \log \left(R G D P_{t}\right)+0.01 * \log \left(R F R_{t}\right)+0.35 * \log \left(R I N V_{t}\right) \\
& 0.56 * \log \left(R P C_{t}\right)+0.51 * \log \left(R G C_{t}\right)+1.89 * \log \left(P M P D_{t}\right)+\xi_{t}
\end{aligned}
$$

Table 5 illustrates the PP unit root test result for residual which indicates that the residual is integrated at 5\% level, so the hypothesis of cointegration is accepted, then there exists an error correction representation

Table 5. PP Unit Root Test for Residual

\begin{tabular}{lc}
\hline & Level \\
\hline Residuals & $-8.677854^{\mathrm{a}}$ \\
\hline a indicates significance at 5\% level.
\end{tabular}

Table 6 and Table 7 give the results of the Likelihood Ratio tests based on the Maximum Eigenvalue and the Trace of the stochastic matrix respectively according to Johansen and Julesius $(1988,1992)$. Both these tests confirm the existence of cointegrating vectors between the variables, i.e. the existence of long-run relationship between them.

Table 6. Cointegration Test Based on Trace of the Stochastic Matrix

\begin{tabular}{ccccc}
\hline Hypothesized No. of CE(s) & Eigenvalue & Trace Statistic & 0.05 Critical Value & Prob.** \\
\hline None * & 0.757173 & 176.8975 & 125.6154 & 0.0000 \\
At most 1 * & 0.545919 & 117.4504 & 95.75366 & 0.0007 \\
At most 2* & 0.522271 & 84.29223 & 69.81889 & 0.0023 \\
At most 3* & 0.453890 & 53.26637 & 47.85613 & 0.0142 \\
At most 4 & 0.363859 & 27.85913 & 29.79707 & 0.0823 \\
At most 5 & 0.178342 & 8.861060 & 15.49471 & 0.3784 \\
At most 6 & 0.014441 & 0.610961 & 3.841466 & 0.4344 \\
\hline
\end{tabular}

Trace test indicates 4 cointegrating eqn(s) at the 0.05 level

* denotes rejection of the hypothesis at the 0.05 level

Table 7. Cointegration Test Based on Maximal Eigenvalue of the Stochastic Matrix

\begin{tabular}{ccccc}
\hline Hypothesized No. of CE(s) & Eigenvalue & Max-Eigen Statistic & 0.05 Critical Value & Prob.** \\
\hline None $*$ & 0.757173 & 59.44710 & 46.23142 & 0.0012 \\
At most 1 & 0.545919 & 33.15815 & 40.07757 & 0.2438 \\
At most 2 & 0.522271 & 31.02585 & 33.87687 & 0.1055 \\
At most 3 & 0.453890 & 25.40724 & 27.58434 & 0.0926 \\
At most 4 & 0.363859 & 18.99807 & 21.13162 & 0.0969 \\
At most 5 & 0.178342 & 8.250099 & 14.26460 & 0.3538 \\
At most 6 & 0.014441 & 0.610961 & 3.841466 & 0.4344 \\
\hline
\end{tabular}

Max-eigenvalue test indicates 1 cointegrating eqn(s) at the 0.05 level

* denotes rejection of the hypothesis at the 0.05 level

Since these variables are cointegrated, they can be represented equivalently in terms of a short run OLS regression. Then, the next step is to construct the error correction model, which represents the short-run dynamics.

$$
\begin{aligned}
& \Delta \log \left(R M I_{t}\right)=0.02+0.91 * \Delta \log \left(R G D P_{t}\right)-0.03 * \Delta \log \left(R F R_{t}\right)+0.6 * \Delta \log \left(R I N V_{t}\right)+0.76 * \Delta \log \left(R P C_{t}\right) \\
& +0.2 * \Delta \log \left(R G C_{t}\right)+2.73 * \Delta \log \left(P D P M_{t}\right)-0.84 * E C T_{t-1}+\xi_{t}
\end{aligned}
$$

The robustness of the model has been definite by several diagnostic tests as shown in Tables (A-4), (A-5), (A-6) and (A-7) in the appendix, such as Breusch- Godfrey serial correlation LM test, Breusch-Pagan-Godfrey Heteroskedasticity test, ARCH test and Jacque-Bera normality test. All the tests disclosed that the model has the aspiration econometric properties, it has a correct functional form and the model's residuals are serially uncorrelated, normally distributed and 
homoskedastic. Therefore, the outcomes reported are serially uncorrelated, normally distributed and homoskedastic. Hence, the results reported are valid for reliable interpretation.

The stability of the long-run coefficient is tested by the short-run dynamics. Once the ECM model given by equation (4) has been estimated, the cumulative sum of recursive residuals (CUSUM) and the CUSUM of square (CUSUMSQ) tests are applied to assess the parameter

stability (Pesaran \& Pesaran (1997)). Figure 4 plot the results for CUSUM and CUSUMSQ tests. The results indicate the absence of any instability of the coefficients because the plot of the CUSUM and CUSUMSQ statistic fall inside the critical bands of the $5 \%$ confidence interval of parameter stability.

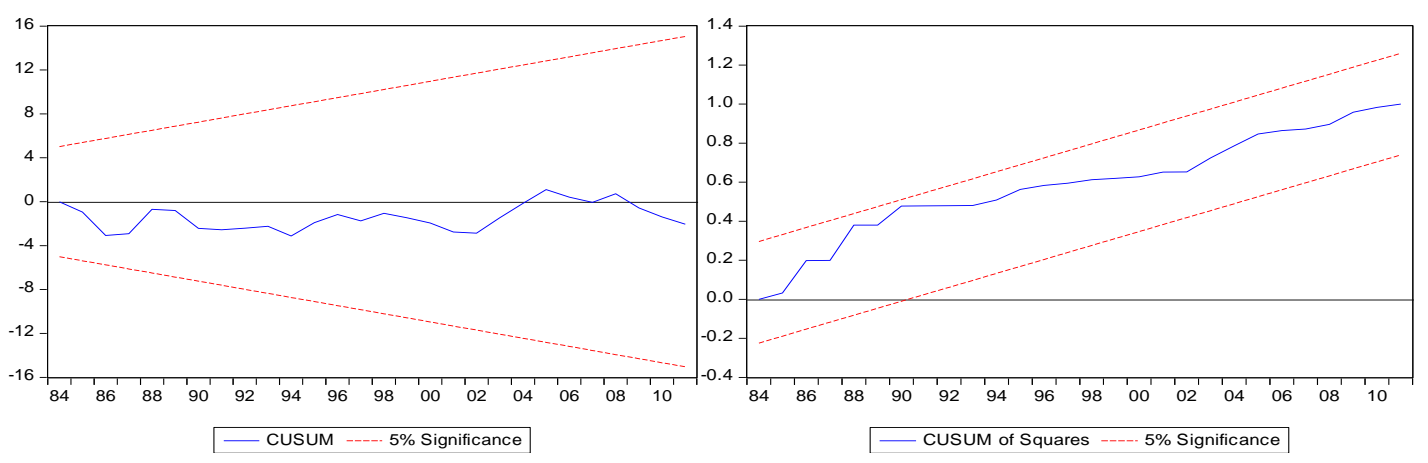

Figure 4. Parameters Stability Tests of Short-run Model

The error correction is correctly negatively signed and highly significant and has a high magnitude (-0.84) suggesting a speed adjustment process, which means that, if merchandise import demand is 1 percent out of equilibrium, a 84 percent adjustment towards equilibrium will take place within the first year.

Table 8 summarizes the critical parameters of merchandise import demand determinants for Saudi Arabia for the period 1975-2011 by using ordinary least squares (OLS) and error correction model approach. The empirical results confirm that, in both long run and short run, there are positive and significant relationships between the demand for merchandise imports and real gross domestic product, gross capital formation expenditure, private consumption expenditure, government consumption expenditure and the relative price of imports to domestic price. On the other hand, there are positive but insignificant relationship between the demand for merchandise imports and international reserves either in the long run or the short run.

Table 8. OLS Estimates for the Long Run and Short Run (1975-2011)

\begin{tabular}{ccc}
\hline \multirow{2}{*}{ Variable } & \multicolumn{2}{c}{ Coefficient } \\
\cline { 2 - 3 } & Long Run & Short Run \\
\hline C & -2.89 & 0.02 \\
$\log ($ RGDP $)$ & $0.81^{\mathrm{a}}$ & $0.91^{\mathrm{a}}$ \\
$\log ($ RFR $)$ & 0.01 & -0.03 \\
$\log ($ RINV $)$ & $0.35^{\mathrm{b}}$ & $0.6^{\mathrm{a}}$ \\
$\log (\mathrm{RPC})$ & $0.56^{\mathrm{a}}$ & $0.76^{\mathrm{a}}$ \\
$\log (\mathrm{RGC})$ & $0.51^{\mathrm{a}}$ & 0.20 \\
$\log (\mathrm{PMPD})$ & $1.98^{\mathrm{a}}$ & $2.73^{\mathrm{a}}$ \\
ECT(-1) & - & $-.84^{\mathrm{a}}$ \\
\hline
\end{tabular}

Source: Table (A-2) and table (A-3) in Appendix.

- $a$ and $b$ denotes significance level at $1 \%$ and $5 \%$ respectively.

\section{Concluding Remarks and Policy Implications}

Total merchandise imports in Saudi Arabia is growing steadily and very rapidly, at an average growth rate of 10.04 percent/year during 1975-2011. So, this study is very important to know the merchandise imports determinants in Saudi Arabian economy. This study empirically estimates the critical parameters of merchandise imports function in Saudi Arabia for the period 1975-2011 by using ordinary least squares (OLS) and error correction model approach. The empirical results obtained show that, in both long run and short run, there are positive and significant relationships 
between the demand for merchandise imports and real gross domestic product, gross capital formation expenditure, private consumption expenditure, government consumption expenditure and the relative price of imports to domestic price. On the other hand, there are positive but insignificant relationship between the demand for merchandise imports and international reserves either in the long run or the short run.

The error correction is correctly negatively signed and highly significant and has a high magnitude $(-0.84)$ suggesting a speed adjustment process, which means that, if merchandise imports is one percent out of equilibrium, a 84 percent adjustment towards equilibrium will take place within the first year.

According to the above discussions although merchandise trade account is achieving a surplus for sixteen years, the merchandise imports increases dramatically and the services account balance is suffering from increasing deficit which swallowing the most of merchandise account balance surplus. Upon these results, government should put in place measures to ensure controlling merchandise and services imports discipline. The efforts of the government should ensure policy consistency, this should be taken into consideration in the formulation and implementation of importing procedures by the way that not to affect international competitiveness and necessary domestic requirements.

Tables:Appendix (A)

Table (A-1). Economic Data (1975-2011)

\begin{tabular}{|c|c|c|c|c|c|c|c|}
\hline \multirow{6}{*}{ Period } & Real & Real Gross & Real & Real Gross & Real Gross & Real Gross & \multirow{6}{*}{$\mathrm{CPI}_{\mathrm{sa}} / \mathrm{CPI}_{\mathrm{us}}$} \\
\hline & Merchandise & Domestic & International & Capital & Government & Household & \\
\hline & Imports & Product & Reserves & Formation & Expenditure & Expenditure & \\
\hline & $(2005=100)$ & $(2005=100)$ & $(2005=100)$ & $(2005=100)$ & $(2005=100)$ & $(2005=100)$ & \\
\hline & (Billion & (Billion & (Billion & (Billion & (Billion & (Billion & \\
\hline & Dollar) & Riyal) & Dollar) & Riyal) & Riyal) & Riyal) & \\
\hline 1975 & 15.29 & 271.02 & 85.71 & 44.87 & 39.59 & 44.87 & 2.19 \\
\hline 1976 & 29.83 & 283.64 & 93.72 & 48.07 & 47.93 & 48.07 & 2.73 \\
\hline 1977 & 47.22 & 294.85 & 97.99 & 77.47 & 54.14 & 77.47 & 2.85 \\
\hline 1978 & 61.13 & 312.57 & 60.54 & 99.39 & 76.02 & 99.39 & 2.61 \\
\hline 1979 & 65.81 & 426.44 & 58.14 & 134.29 & 92.46 & 134.29 & 2.37 \\
\hline 1870 & 71.49 & 595.96 & 61.93 & 149.47 & 94.84 & 149.47 & 2.17 \\
\hline 1981 & 75.77 & 659.89 & 73.16 & 175.64 & 129.25 & 175.64 & 2.03 \\
\hline 1982 & 82.25 & 550.35 & 64.05 & 200.48 & 144.42 & 200.48 & 1.93 \\
\hline 1983 & 76.86 & 466.53 & 56.94 & 210.88 & 139.20 & 210.88 & 1.87 \\
\hline 1984 & 63.34 & 447.50 & 49.18 & 214.20 & 135.24 & 214.20 & 1.77 \\
\hline 1985 & 42.87 & 413.23 & 48.11 & 219.90 & 131.83 & 219.90 & 1.65 \\
\hline 1986 & 34.05 & 365.30 & 35.85 & 200.76 & 126.64 & 200.76 & 1.57 \\
\hline 1987 & 34.54 & 369.79 & 42.78 & 197.21 & 130.25 & 197.21 & 1.49 \\
\hline 1988 & 35.97 & 377.41 & 37.05 & 201.00 & 116.75 & 201.00 & 1.45 \\
\hline 1989 & 33.33 & 403.56 & 29.29 & 206.99 & 135.58 & 206.99 & 1.39 \\
\hline 1990 & 35.98 & 484.22 & 20.08 & 226.02 & 141.53 & 226.02 & 1.35 \\
\hline 1991 & 41.70 & 519.34 & 19.07 & 229.75 & 178.58 & 229.75 & 1.36 \\
\hline 1992 & 46.90 & 539.40 & 10.39 & 239.64 & 161.35 & 239.64 & 1.32 \\
\hline 1993 & 38.12 & 517.50 & 12.47 & 248.60 & 136.96 & 248.60 & 1.29 \\
\hline 1994 & 30.75 & 523.07 & 12.04 & 250.04 & 127.43 & 250.04 & 1.27 \\
\hline 1995 & 36.00 & 528.98 & 13.33 & 248.16 & 124.85 & 248.16 & 1.29 \\
\hline 1996 & 34.54 & 578.66 & 19.94 & 254.18 & 141.82 & 254.18 & 1.27 \\
\hline 1997 & 34.96 & 604.92 & 19.72 & 255.93 & 158.39 & 255.93 & 1.24 \\
\hline 1998 & 35.96 & 537.08 & 18.62 & 247.02 & 152.48 & 247.02 & 1.22 \\
\hline 1999 & 32.84 & 601.12 & 21.49 & 251.19 & 153.47 & 251.19 & 1.18 \\
\hline
\end{tabular}




\begin{tabular}{llllllll}
2000 & 34.29 & 711.78 & 23.64 & 260.00 & 185.14 & 260.00 & 1.13 \\
2001 & 34.44 & 699.05 & 20.81 & 264.37 & 192.20 & 264.37 & 1.08 \\
2002 & 35.06 & 718.55 & 24.09 & 264.63 & 187.51 & 264.63 & 1.07 \\
2003 & 44.27 & 812.95 & 26.05 & 272.76 & 200.19 & 272.76 & 1.05 \\
2004 & 48.98 & 945.34 & 30.30 & 287.70 & 223.35 & 287.70 & 1.03 \\
2005 & 59.46 & 1182.51 & 157.39 & 312.96 & 262.65 & 312.96 & 1.00 \\
2006 & 67.62 & 1306.74 & 221.80 & 347.25 & 304.36 & 347.25 & 0.99 \\
2007 & 84.97 & 1354.93 & 291.31 & 395.64 & 302.52 & 395.64 & 1.00 \\
2008 & 104.43 & 1526.94 & 409.34 & 415.52 & 295.02 & 415.52 & 1.06 \\
2009 & 86.98 & 1149.37 & 383.22 & 443.14 & 290.49 & 443.14 & 1.12 \\
2010 & 95.71 & 1305.70 & 411.36 & 462.74 & 290.39 & 462.74 & 1.16 \\
2011 & 114.30 & 1591.03 & 483.21 & 479.81 & 314.24 & 479.81 & 1.18 \\
\hline
\end{tabular}

Source:Saudi Arabian Monetary Agency (SAMA), Annual Report, No. 48.

- World Bank, World Bank Development Indicator.

Table (A-2). Ordinary Least Squares Regression Results (Long Run Relationship)

Dependent Variable: LOG(RMI)

Method: Least Squares

Date: 11/08/14 Time: 10:08

Sample (adjusted): 19752011

Included observations: 37

\begin{tabular}{llllc}
\hline \multicolumn{1}{c}{ Variable } & Coefficient & \multicolumn{1}{c}{ Std. Error } & t-Statistic & Prob. \\
\hline LOG(RGDP) & 0.809828 & 0.094408 & 8.577963 & 0.0000 \\
LOG(RFRI) & 0.007123 & 0.023715 & 0.300336 & 0.7660 \\
LOG(RINVI) & 0.351419 & 0.137453 & 2.556637 & 0.0159 \\
LOG(RPCI) & 0.562513 & 0.133063 & 4.227420 & 0.0002 \\
LOG(RGCI) & 0.508148 & 0.181505 & 2.799642 & 0.0089 \\
LOG(CPISA/CPIUSA) & 1.981571 & 0.124006 & 15.97958 & 0.0000 \\
C & -2.893791 & 0.157218 & -18.40625 & 0.0000 \\
\hline R-squared & 0.959686 & Mean dependent var & -2.524235 \\
Adjusted R-squared & 0.951623 & S.D. dependent var & 0.397305 \\
S.E. of regression & 0.087386 & Akaike info criterion & -1.868306 \\
Sum squared resid & 0.229089 & Schwarz criterion & -1.563538 \\
Log likelihood & 41.56366 & Hannan-Quinn criter. & -1.760861 \\
F-statistic & 119.0267 & Durbin-Watson stat & 1.650076 \\
Prob(F-statistic) & 0.000000 & \multicolumn{3}{c}{} \\
\hline
\end{tabular}

Table (A-3). Ordinary Least Squares Regression Results (Short Run Relationship)

Dependent Variable: D(LOG(RMI)

Method: Least Squares

Date: 11/08/14 Time: 10:26

Sample (adjusted): 19762011

Included observations: 36 after adjustments

\begin{tabular}{rcccc}
\hline Variable & Coefficient & Std. Error & t-Statistic & Prob. \\
\hline $\mathrm{D}($ LOG(RGDP) $)$ & 0.907539 & 0.163135 & 5.563102 & 0.0000
\end{tabular}




\begin{tabular}{lllll}
\hline D(LOG(RFRI) & -0.027873 & 0.039507 & -0.705528 & 0.4863 \\
D(LOG(RINVI) & 0.603680 & 0.159141 & 3.793362 & 0.0007 \\
D(LOG(RPCI) & 0.757664 & 0.147595 & 5.133399 & 0.0000 \\
D(LOG(RGCI) & 0.201512 & 0.133185 & 1.513026 & 0.1415 \\
D(LOG(CPISA/CPIUSA)) & 2.732837 & 0.295677 & 9.242641 & 0.0000 \\
RESID01(-1) & -0.842566 & 0.167256 & -5.037584 & 0.0000 \\
C & 0.021341 & 0.017392 & 1.227036 & 0.2300 \\
\hline R-squared & 0.881209 & Mean dependent var & 0.006721 \\
Adjusted R-squared & 0.851511 & S.D. dependent var & 0.188919 \\
& \multicolumn{5}{c}{ Akaike info } \\
S.E. of regression & 0.072799 & criterion & -2.209105 \\
Sum squared resid & 0.148391 & Schwarz criterion & -1.857212 \\
& \multicolumn{5}{c}{ Hannan-Quinn } \\
Log likelihood & 47.76389 & criter. & -2.086285 \\
F-statistic & 29.67245 & Durbin-Watson stat & 1.868520 \\
Prob(F-statistic) & 0.000000 & & \\
\hline
\end{tabular}

Table (A-4). Breusch- Godfrey serial correlation LM test for Short-run Model

\begin{tabular}{llll}
\hline F-statistic & 0.262308 & Prob. F(1,27) & 0.6127 \\
\hline Obs*R-squared & 0.346378 & Prob. Chi-Square(1) & 0.5562 \\
\hline
\end{tabular}

Table (A-5). Residuals Breusch-Pagan-Godfrey Heteroskedasticity Test of Short-run Model

\begin{tabular}{llll}
\hline F-statistic & 0.687485 & Prob. F(7,28) & 0.6816 \\
\hline Obs*R-squared & 5.279900 & Prob. Chi-Square(7) & 0.6258 \\
\hline
\end{tabular}

Table (A-6). Residuals ARCH Heteroskedasticity Test of Short-run Model

\begin{tabular}{llll}
\hline F-statistic & 1.526795 & Prob. F(1,33) & 0.2253 \\
\hline Obs*R-squared & 1.547720 & Prob. Chi-Square(1) & 0.2135 \\
\hline
\end{tabular}

Table (A-7). Residuals Normality Test of Short-run Model

\section{References}

\begin{tabular}{ll}
\hline Jarque-Bera & Prob. \\
\hline 2.175160 & 0.337031 \\
\hline
\end{tabular}

Aljebrin, M. A., \& Ibrahim, M. A. (2012). The Determinants of the Demand for Imports in GCC Countries. International Journal of Economics and Finance, 4(3), 126-138.

Al-Dakhil, K., \& Al-Yousef, N. (2002). Aggregate import demand function for Saudi Arabia: An error correction approach. Journal of Economic \& Administrative Sciences, 18, 83-100

Alias, H. M., \& Tang, T. C. (2000). Aggregate imports and expenditure components in Malaysia: A cointegration and error correction analysis. ASEAN Economic Bulletin, 17, 257-69. http://dx.doi.org/10.1355/AE17-3B

Arab Monetary Fund (AMF), Arab monetary Fund (AMF), http://www.amf.org.ae/ctrylisten/54/Foreign\%20Trade.

Bahmani-Oskooee, M. (1998). Cointegration approach to estimate the long-run trade elasticities in LDCs. International Economic Journal, 12, 89-96.

Bencivenga, V., \& Smith, B., (1991). Financial intermediation and endogenous growth. Review of Economics and Studies, 58, 195-209.

Breusch, T. S., \& Pagan, A. R. (1979). A Simple Test for Heteroscedasticity and Random Coefficient Variation. Econometrica, 47(5), 1287-1294.

Carone, G. (1996). Modeling the U. S. demand for imports through cointegration and error correction. Journal of Policy Modeling, 18, 1-48. http://dx.doi.org/10.1016/0161-8938(95)00058-5.

Doroodian et al (1994). An examination of the traditional import demand function for Saudi Arabia. Applied Economics, 
26, 909-915. http://dx.doi.org/10.1080/00036849400000052.

Dutta, D., \& Ahmed., N. (2006). An aggregate import demand function for India: A cointegration analysis. School of Economics and Political Science, University of Sydney, Australia. Retrieved from https://digitalcollections.anu.edu.au/handle/1885/40314

Engle, R. F., \& Granger, W. J. (1987). Cointegration and Error Correction: Representation, Estimation and Testing. Econometrica, 55(2), 251-76. http://www.jstor.org/pss/1913236.

Erlat, G., \& Erlat, H. (1991). An empirical study of Turkish export and import function. CBRT and METU.

Hicks A. (1994). Introduction to pooling. In T. Janoski and A. Hicks (edited by), The Comparative Political Economy of the Welfare State, Cambridge University Press, UK.

Intenational Monetary Fund (IMF). Policy challenges in the Gulf Cooperation Council Countries. http://www.imf.org/external/pubs/ft/policy/3oilmkt.htm.

Jarque, C. M., \& Bera, A. K. (1981). Efficient tests for normality, homoscedasticity and serial independence of regression residuals: Monte Carlo evidence. Economics Letters, 7(4): 313-318. http://dx.doi.org/10.1016/0165-1765(81)90035-5

Johansen, S., \& Juselius, K. (1992). Testing Structural Hypothesis in a Multivariate Cointegration Analysis of the PPP and the UIP for UK. Journal of Econometrics, 53,211-44.

Kotan Z., \& Saygili, M. (1999). Estimating an import demand function For Turkey. Discussion paper, The Central Bank of the Republic of Turkey, Research Department,Turkey. http://www.tcmb.gov.tr/research/discus/dpaper40.pdf. http://dx.doi.org/10.1016/S0304-4076(01)00098-7

Metwalli, M. (2004). Determinants of aggregate imports in the GCC Countries. Applied Econometrics and International Development (AEID), 4-3, 59-76. Retrieved from http://papers.ssrn.com/sol3/papers.cfm?abstract_id=1232342.

Mohammed, H. A., \& Tang, T. C. (2000). Aggregate imports and expenditure components in Malaysia: A cointegration and error correction analysis. ASEAN Economic Bulletin, 17, 257-269. http://web.williams.edu/Economics/wp/pedronipanelcointegration.pdf.

Pesaran, M. H., \& Pesaran, B. (1997). Working with Microfit 4.0: Interactive Econometric Analysis. Oxford University Press, Oxford.

Phillips, P. C., \& Perron, P. (1988). Testing for a unit root in time series regression. Biometrika, 75, 335-346.

Saudi Arabian Monetary Agency (SAMA) (2014), Annual Report, http://www.sama.gov.sa/ReportsStatistics/Pages/AnnualReport.aspx.

Sinha, D. (2001). A Note on Trade Elasticities in Asian Countries. The International Trade Journal, XV, 221-237.

Stirbock, C. (2006). How strong is the impact of exports and other demand components on German import demand? Evidence from euro-area and non-euro-area imports. Discussion paper. Economic studies, 1, Deutsche Bundesbank Frankfurt, Germany. http://econstor.eu/bitstream/10419/19668/1/200639dkp.pdf.

World Bank, World Bank Developmevt Indicator, http://data.worldbank.org/indicator/

\section{$(\mathrm{cc}) \mathrm{BY}$}

This work is licensed under a Creative Commons Attribution 3.0 License. 